\title{
The effect of companies' employment of their ex-auditors on their Audit Quality: Evidence from UK
}

\author{
Laila Mohamed Alshawadfy AlAdwey*
}

(*) Laila AlAdwey is a lecturer in accounting, Faculty of Commerce, Tanta University.

She got her PhD in Accounting from Tanta University, Egypt in joint supervision mission with Glasgow University, UK. She also got a Certificate in Social Science Research Methods from College of Social Sciences, University of Glasgow; and Master and BCom degrees in Accounting from Tanta University, Egypt. She is FHEA Descriptor 2 as recognized from TeachBU Bournemouth University, UK. In addition, she is recognized as GTA from Learning and Teaching Centre, University of Glasgow, UK and as Certified Trainer, Training of Training (TOT), awarded from International Center for Faculty and Leadership Development, Tanta University, Egypt. Also, she is granted Special Appreciation from Arab Administrative Development Organization in the conference of Sharjah PhD Award.

Email: laila.eladawi@commerce.tanta.edu.eg 


\section{Abstract}

The UK regulatory bodies mandated two years cooling off period before the former audit team members can hold a managerial position within the client firm. The pertinent literature indicates mixed results around the implications of the companies' employment of their exauditors or what is called Auditor to Client Revolving Door practise (ACRD) on the audit quality. The aim of this paper is to examine the effect of ACRD hires on the audit quality for UK FTSE100 companies for the period from 2008 to 2018. Using the Kothari et al. (2005) model to calculate the absolute value of abnormal accruals, the paper finds that companies with ACRD hires demonstrates lower levels of the absolute accruals compared to other companies with no ACRD hires. This indicates the positive, rather than negative, effect of ACRD employment on the audit quality. Further insights on the corporate hierarchal positions of the ACRD hires reveals that the affiliated non-executive directors that are members in the audit committees significantly reduce the levels of the absolute accruals, highlighting their oversight and governance role. The paper also finds the inescapable of the cooling-off period in enhancing the audit quality for the companies with affiliated compared to those with non-affiliated hires.

Keywords: Auditor to Client Revolving Door, Audit Quality, Earning Management Abnormal Accruals, Cooling off Period, UK FTSE100.

الكلمات المفتاحية: من باب المراجع لباب العميل، جودة المراجعة ، إدارة أرباح ، المستحقات غير

العادية ، فترة التهدئة، المملكة المتحدة FTSE100 .

فرضت الهيئات التنظيمية في المملكة المتحدة فترة تهئةة لمدة عامين حتي يتمكن أحد أعضاء فريق المراجعة السابق من شغل منصب إداري داخل شركة العميل وتسمي هذه الظاهرة من باب المراجع لباب العميل(ACRD). تشير الأدبيات ذات الصلة إلي نتائج مختلطة حول الآثار المترتبة لهذه الظاهرة علي جودة المراجعة. الهدف من هذا البحث هو فحص تأثيرهذا النوع من التوظيف

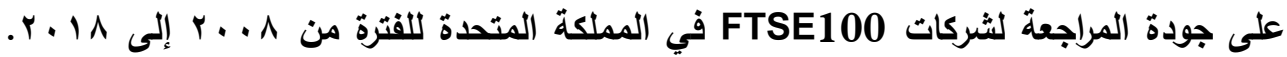
توصلت الاراسة بإستخدام Kothari et al. (2005) لحساب القيمة المطلقة للاستحقاقات غير العادية إلي أن الثركات التي تقوم بتعيين أحد أعضاء فريق المراجعة السابق لايها تظهر مستويات أقل من الاستحقاقات مقارنة بالشركات الأخرى التي ليس لايها مثل هذه التعيينات. يشير ذلك إلى التأثير الإيجابي لتوظيف المراجعين على جودة المراجعة في شركات العملاء. بالإضافة لألك أوضحت الاراسة أن المديرين غير التنفيذيين المنتسبين لمكتب المراجعة السابق وفي نفس الوقت أعضاء بلجان المراجعة بساهموا بشكل كبير في تقليل مستويات الاستحقاقات 
المطلقة و ذلك لاورها الرقابي و الحوكمي. أَظهرت النتائج أيضا أن فترة التهئية لا مفر منها في تعزيز جودة المراجعة للثركات التي لايها تعينات لأعضاء فريق المراجعة السابق مقارنة لابها بالثركات الأخرى التي ليس لايها مثل هذه التعيينات.

\section{Introduction}

Audit quality can be defined as the joint probability that auditors detect and report deficiencies in their client's firms (DeAngelo, 1981). The likelihood that auditors detect such deficiencies is a function of their competence and effort and management's ability to manipulate earning figures (Lennox and Park, 2007 and Sitanggang et al., 2019). Also, the auditors' likelihood to report rather than ignore or hide any fraud or deficiencies depends on their independence (DeAngelo, 1981 and Tepalagul and Lin, 2015). The employment of the former audit team members within the client firm, or Auditor to Client Revolving Door (ACRD), is a practice that is detected in most companies suffering from famous financial scandals; hence it gives some implications toward impairing the audit quality and auditor's independence (Lennox and Park, 2007 and Geiger et al., 2008). The regulatory bodies address their concern toward the consequence such implications by issuing specific rules that govern or mitigate the ACRD practice. Specifically, based upon Sarbanes-Oxley Act in 2002, the SEC prohibits members of the audit engagement team from working for the client firm in certain key management positions during the one-year "cooling off" period before ending the auditing engagement. In a similar vein, Financial Reporting Council (FRC) identified a period of two years as the restriction period upon which an ex-partner or other audit engagement members can join the client's firm in a managerial position (Revised ES, 2019:2.43, p.44). (Revised ES, 2019:2.44, p.44)

Trucking the literature around the ACRD and its implication in audit quality reveals mixed results. Tepalagul and Lin (2015) argued the effect of the companies' director's affiliation with audit firm on audit quality in the pertinent literature are sparse and conflicting. Two conflicting views are found. A strand of researchers (e.g. Menon and Williams, 2004 and Lennox, 2005) articulates the negative consequence on the audit quality by arguing that social ties of the affiliated directors with the audit engagement team 
create a level of familiarity and intimacy that affect the team's level of assessed risk and dwindle the governance role of the external auditors. Another strand of researchers (e.g. Geiger et al., 2008 and Bird et al., 2015) indicates the positive impact of ACRD on boosting the audit quality since the knowledge and the auditing and industrial experience of affiliated directors would add value to the auditing process and clarify the relationship with the audit firm. Accordingly, the aim of the paper is to examine the effect of ACRD practices on the audit quality proxied by the level of absolute discretionary accruals earning management within UK.

Most of the empirical papers that investigated the practice of ACRD are conducted within USA such as (Menon and Williams, 2004; Geiger et al. 2005,2008; Lennox and Park, 2007; Baber et al.,2014; Bird et al., 2015...). As argued by Hofstede (2001), there is a lot of organizational differences between USA and UK companies, although both of them are operating in developed countries. In a structured literature review around ACRD, Kotb et al. (2018) indicated that UK is one of the least countries that is utilized as a regional setting for examining the insights of ACRD within. Few studies are examined the implications of ACRD on audit quality within UK such as (Basioudis, 2007 and Dart and Chandler, 2013). Aside from Basioudis, (2007) who investigated the effect the ACRD practice on the audit fees, and Dart and Chandler (2013) who studied the perceptions of private and institutional investors toward the threats associated with the affiliated directors in the audit firm to the auditor independence and how such perceptions would affect their investment decisions; the paper go a furthered step. the paper aimed at measuring the impact of ACRD practice within UK FTSE100 companies in the audit quality as measured by the absolute value of discretionary accrual for the period from 2008 to 2018. The covered sample period is from January 2008 to December 2018 at which the regulatory bodies with the UK were recommend the prohibition of the practice of ACRD. The frequency of ACRD hires was 14.6 percent of the sample, which represent the ratio of the auditor-affiliated directors within UK FTSE100 companies that directly join their client firms.

The findings of the paper can be summarized as follows. First, the paper provided empirical evidence that ACRD practice has positive implications 
in the audit quality for the UK companies. Based on the absolute discretionary accrual earning management of Kothari et al. 2005, the results indicating that that companies with affiliated directors report lower absolute accruals than companies with non-affiliated directors. Second, in order to get more insights about the ACRD practice, the paper assorted the affiliated hire in the sample into four groups according to their corporate hierarchal positions. This classification yields four different groups arranged from the higher to the lower rank as follows, the affiliated directors hold executive position, the affiliated directors, affiliated non-executive directors that are audit committee's members and, and the affiliated non-executive directors. The results indicate that compared to the other groups, the affiliated nonexecutive directors membered the audit committee are contributed positively to the audit quality as evident in their negative association with absolute discretionary accrual. Their positions enable them to directly engage with the audit engagement team all-over the auditing process, beginning from settling the auditor's engagement until the final audit report is issued. The auditing experience and knowledge and the social relationship and ties they own from their former work in the audit firm authorize them to oversight the auditing process in much smoother and flexible way than other nonaffiliated directors.

The paper contributes to the literature in several ways. First, subject to the rare empirical papers that examine the implication of ACRD practice within the UK, the paper reveals the positive consequences of such practice as evident by the lower absolute accrual for the companies with affiliated hires compared to those with non-affiliated hires. Second, it indicates the importance of the expertise hold by the affiliated directors in enhancing the audit quality. Their former experience in the client firm and industry, their working experience in the audit firm and their interrelationship and social ties are all positively contributing to the auditing process. Third, the paper demonstrates the importance of ACRD affiliations for nonexecutive directors of audit committee's members in scrutinizing the audit function. Fourth, the paper stipulates the substance of the cooling off period in offsetting the regulators' concerns toward the ACRD hires' imputations on audit quality. 
The remainder of this paper is structured as follows. Section 2 reviews the pertinent literature and develops the hypotheses. Section 3 defines the main variables discusses the used methodology. Section 4 demonstrates the descriptive statistics, the discussion and demonstrates further analysis. Finally, section 5 concludes the results.

\section{Literature Review and Hypotheses Development}

The relationship between ACRD and audit quality has frequently examined in the literature, but mixed results are reported. In this regard, two contradicted views are provided. The first is related to potential negative impact of the practice of ACRD. When a former auditor joins the client firm, s/he comes with a set of expertise, knowledge and relational links that, if badly exploited, may impair the audit quality and auditor independence (Menon and Williams, 2004 and Lennox, 2005). Affiliated auditors acquire sufficient knowledge about audit procedures and the type and extent of their former auditing firm's auditing tests. They could exploit such knowledge to fudge the designed auditing procedures (Lennox, 2005) and engage in earning management practises with less likely to be detected (Bird et al., 2015). Besides, former auditors may be personally engaged with audit team members working in their affiliated auditing firm. This engagement would induce the current audit team to trust in the work performed by former colleagues, exert less audit effort to verify their assertions and be more flexible in modifying audit procedures and tests (Lennox, 2005 and Barber et al. 2014). In other terms, according to the audit risk model, the trust in the affiliated auditor induces the audit team to lower the assessed level of control and inherent risk (Menon and Williams 2004). These relational links may also minimize the auditors' professional scepticism and, consequently, impair their independence (Bird et al., 2015).

The second view argued the positive effect of ACRD. The intimated and social relationships between the former auditor and the audit team would enhance the quality of auditing due to their willingness to discuss and cooperate in a manner that may add value to the auditing process (Geiger et al., 2008 and Bird et al., 2015). In addition, based upon their previous work experience in the audit firm, affiliated auditors acquire extensive knowledge about the clients' business processes; internal control systems and financial 
reporting requirements (Naiker and Sharma, 2009) and also gain specialized knowledge in client's specific industry and market (Ferguson et al. 2003). Hence, compared to other candidates, they could handle the required tasks in a much effective way (Geiger et al., 2008). Moreover, the familiarity of affiliated auditors with quality control procedures performed by the audit firm and the personal relationships they utilise with the engagement audit team would evoke straightforward debate around the critical and challenging issues and help in mitigating any tension between management and audit firm (Naiker and Sharma, 2009). Furthermore, the situation in which affiliated auditors join the client firm would give positive clues to shareholders and the market as a whole about the company's future since the auditors already have sufficient information about its internal business situation (Geiger et al., 2008). Neglecting the potential merits of ACRD in enhancing audit quality to cope with current regulations may be inconsistent with the intention of such regulation from the outset. Menon and Williams (2004) argued that although the concerns toward the negative effect of ACRD, the US Independence Standards Board (ISB) formerly contended the practice of hiring affiliated auditors would enhance the credibility of reported financial statement subject to their considerable knowledge and experience. Also, given the relatively stable level of accounting accrual after and before ACRD, as reported by their results, Geiger et al. (2005) clearly stated that they are not advocating the regulations' concern toward impaired audit quality resulting from affiliation practise. Similarly, Naiker and Sharma (2009) argued that since the overall goal of SOX is to enhance audit quality, the cooling-off period may prevent the client firm from utilizing considerable experience and knowledge that could posit the financial reporting quality. Moreover, Bird et al. (2015) consistent with Geiger et al. (2008) undermined the value of the SOX restriction due to the paucity of detected empirical evidence of the association of ACRD and adverse effect on reporting quality.

\subsection{Hypothesis Development 2.2.1 ACRD and Its Implication on Audit Quality}

Following Sox and other regulations, researchers tried to articulate the implications of ACRD in audit quality. A stream of papers indicating the 
negative consequences of ACRD as evidenced by the impairment of the audit quality. Menon and Williams (2004) compared the level of abnormal accruals as a proxy of audit quality between affiliated and non-affiliated in USA public companies for a period before the SOX regulation. They identified the company to be affiliated if it hires executive officers or directors working as partners in the company's current auditing firm. Compared to non-affiliated companies, affiliated companies reported higher signed and absolute abnormal accruals (Menon and Williams, 2004). In a similar vein, Dowdell and Krishnan (2004) examined the effect of affiliated CFOs on the level of earning management as measured by discretionary accrual. They found that the level of signed discretionary accrual for companies with affiliated CFOs is higher for non-affiliated CFOs. Compared to the earlier research, Lennox (2005) provided a broader concept of affiliation that encompasses two types. The first is ACRD, where the auditor disuses the auditing firm to join the client firm. In contrast, the second is related to alma mater affiliation, where the executive officer tried to convince the firm to swap to another auditing firm which was his/her exemployer. Lennox (2005) measured audit quality by the likelihood of a company receiving a modified opinion and found that companies have a higher frequency to receive clean audit report when their executive are previously worked in their companies' audit firms, thus such executive affiliations may deter the audit quality as alleged by the regulations' concerns.

On the other hand, another stream of research valued the importance of experience and knowledge acquired by former auditors in enhancing audit quality by reducing the level of accrual earning management. Geiger et al. (2005) examined the affiliation restrictions identified by SOX and considered the affiliation hires of different categories of executive members such as CFO; CAO; Vice President of Finance and controller who directly join the client firm and were formally working partner or non-partner in the auditing firm. They did not detect any increase in absolute discretionary accruals for companies facing ACRD practice in three periods slots: the year before the affiliated hire, the first year of affiliation, or even within the three years after the hire. With a similar realization, Geiger et al. (2008) found that the market positively reacted to the auditor revolving door hires more 
than other appointments. Besides, they provided empirical evidence that companies with affiliation appointment maintain relatively the same level of discretionary accounting accruals and shows lower chances to receive Accounting and Auditing Enforcement Release (AAER) relative to other non-affiliated companies. Also, Baber et al. (2014) indicate a nonsignificance difference in the level of discretionary accruals between companies with affiliated versus non-affiliated hire. Furthermore, Bird et al., 2015 examine the association of affiliated accounting employees and the audit quality measured by material misstatement and absolute abnormal accruals. Their findings revealed that the higher the number of affiliations a company utilizes, the lower the chance of financial material misstatement and the lower detected levels of absolute abnormal accruals.

A perusal of literature indicates that the implications of ACRD on audit quality are not settled due to the contradicted results reported, as shown Panel A and Panel B in Table I. In addition, Tepalagul and Lin, 2015 referred to the inconsistent results about the impact of auditor-affiliation hold by companies' directors and audit quality. Since there is a lack of consensus among researchers around the direction of implications of ACRD practice on the audit quality, the first hypothesis is stated as follows:

$\mathrm{H}_{1}$. There is a statistical relationship between ACRD and the audit quality.

\begin{tabular}{|c|c|c|c|}
\hline \multicolumn{4}{|c|}{ Panel A: ACRD hires support audit quality. } \\
\hline Reference & $\begin{array}{l}\text { How Audit Quality } \\
\text { are proxied? }\end{array}$ & Sample & Main Findings \\
\hline Lennox (2005) & $\begin{array}{l}\text { Audit quality: The } \\
\text { issuance of clean audit } \\
\text { opinion. }\end{array}$ & $\begin{array}{l}\text { The total sample is } 968 \\
\text { executives with auditing } \\
\text { experience. Of it, } 339 \\
\text { executives are affiliated } \\
\text { and previously working } \\
\text { as auditors. The sample } \\
\text { cover the period from } \\
1995 \text { to } 1998 \text {. }\end{array}$ & $\begin{array}{l}\text { The probability of the } \\
\text { affiliated companies to } \\
\text { receive clean audit } \\
\text { reports are higher than for } \\
\text { unaffiliated companies. }\end{array}$ \\
\hline Geiger et al., (2005) & $\begin{array}{l}\text { Auditor independence: } \\
\text { The degree of total } \\
\text { discretionary accruals. }\end{array}$ & $\begin{array}{l}\text { The sample cover } 101 \\
\text { affiliated hire. for period } \\
\text { from } 1989 \text { to1999. The } \\
\text { affiliation hire } \\
\text { encompasses executive } \\
\text { members such as "CFO," } \\
\text { "Controller," "Vice } \\
\text { President-Finance," or } \\
\text { "Chief Accounting }\end{array}$ & $\begin{array}{l}\text { The paper fails to } \\
\text { recognize any increase in } \\
\text { earning management } \\
\text { subject to the hire of ex- } \\
\text { partner either within one } \\
\text { year before the hire, or in } \\
\text { the first year after the hire } \\
\text { nor for three-years period }\end{array}$ \\
\hline
\end{tabular}


The effect of companies' employment of their ex-auditors on their Audit Quality: Evidence from UK

Laila Mohamed Alshawadfy AlAdwey

\begin{tabular}{|c|c|c|c|}
\hline \multicolumn{4}{|c|}{ Panel A: ACRD hires support audit quality. } \\
\hline Reference & $\begin{array}{c}\text { How Audit Quality } \\
\text { are proxied? }\end{array}$ & Sample & Main Findings \\
\hline & & $\begin{array}{l}\text { Officer" that were } \\
\text { working as managers or } \\
\text { partners in the auditing } \\
\text { firm. }\end{array}$ & \\
\hline Geiger et al. (2008) & $\begin{array}{l}\text { Market reaction to ACRD } \\
\text { and its implications on } \\
\text { financial reporting quality } \\
\text { as measured by } \\
\text { discretionary accruals or } \\
\text { the issuance of an } \\
\text { Accounting and Auditing } \\
\text { Enforcement Release } \\
\text { (AAER). }\end{array}$ & $\begin{array}{l}\text { The sample covered } 3176 \\
\text { senior officers for the } \\
\text { period from January } 1985 \\
\text { to July } 2002 \text {. It addresses } \\
\text { the executive members } \\
\text { exactly as specified by } \\
\text { SOX. }\end{array}$ & $\begin{array}{l}\text { Compared to companies } \\
\text { with non-ACRD cases, } \\
\text { companies with ACRD } \\
\text { maintained similar } \\
\text { degrees of } \\
\text { discretionary accruals and } \\
\text { showed lower } \\
\text { probabilities to receive } \\
\text { (AAER). }\end{array}$ \\
\hline Bird et al. (2015) & $\begin{array}{l}\text { Audi quality: The level of } \\
\text { material misstatement in } \\
\text { financial reporting and } \\
\text { the level of abnormal } \\
\text { accruals. }\end{array}$ & $\begin{array}{l}\text { The sample covers } 63,000 \\
\text { accounting employees } \\
\text { subject to S\&P } 1500 \\
\text { companies for the period } \\
\text { of } 2009 \text { to } 2013 \text {. It } \\
\text { encompasses non- } \\
\text { executive accounting } \\
\text { employees at different } \\
\text { management level and } \\
\text { were previously working } \\
\text { at the existing auditing } \\
\text { firm. }\end{array}$ & $\begin{array}{l}\text { The higher the ACRD } \\
\text { practise for managers } \\
\text { working in accounting } \\
\text { and finances, the higher } \\
\text { the quality of audit. }\end{array}$ \\
\hline $\begin{array}{l}\text { Naiker and Sharma } \\
(2009)\end{array}$ & $\begin{array}{l}\text { Financial reporting } \\
\text { quality related to } \\
\text { internal control: } \\
\text { performance-adjusted } \\
\text { discretionary accruals. }\end{array}$ & $\begin{array}{l}\text { The sample includes } \\
1225 \text { companies that } \\
\text { adhering to SOX' } \\
\text { requirement for } \\
\text { disclosing internal } \\
\text { control deficiencies for } \\
\text { the year } 2004 \text {. }\end{array}$ & $\begin{array}{l}\text { Among other findings, } \\
\text { the paper revealed that } \\
\text { the presence of } \\
\text { affiliated auditors } \\
\text { within audit committee } \\
\text { is negatively correlated } \\
\text { to discretionary } \\
\text { accruals which give } \\
\text { positive implication to } \\
\text { financial reporting } \\
\text { quality. }\end{array}$ \\
\hline \multicolumn{4}{|c|}{ Panel B: ACRD hires impair audit quality. } \\
\hline $\begin{array}{l}\text { Dowdell and Krishnan } \\
\text { (2004) }\end{array}$ & $\begin{array}{l}\text { Audit quality: } \\
\text { Discretionary accrual; } \\
\text { signed and absolute. }\end{array}$ & $\begin{array}{l}172 \text { affiliations hire for } \\
\text { CFOs, in addition to } \\
\text { control sample of non- } \\
\text { affiliation hire for the } \\
\text { period from } 1993 \text { to } \\
1997 \text {. The affiliation hires } \\
\text { encompass only CFO } \\
\text { who were previously }\end{array}$ & \begin{tabular}{lrr} 
Signed & \multicolumn{2}{c}{ discretionary } \\
accruals reported higher \\
levels for & CFOs \\
affiliations rather than \\
non-CFOs hires, while \\
absolute discretionary \\
accruals are non- \\
significantly related to
\end{tabular} \\
\hline
\end{tabular}




\begin{tabular}{|c|c|c|c|}
\hline \multicolumn{4}{|c|}{ Panel A: ACRD hires support audit quality. } \\
\hline Reference & $\begin{array}{l}\text { How Audit Quality } \\
\text { are proxied? }\end{array}$ & Sample & Main Findings \\
\hline & & $\begin{array}{l}\text { working as auditors for } \\
\text { the client firm. }\end{array}$ & both groups. \\
\hline $\begin{array}{l}\text { Menon and Williams } \\
(2004)\end{array}$ & $\begin{array}{l}\text { Auditor independence: } \\
\text { The degree of Abnormal } \\
\text { accruals; signed and } \\
\text { unsigned. }\end{array}$ & $\begin{array}{l}840 \text { firm year observation } \\
\text { for affiliated companies } \\
\text { versus } 10735 \text { of non- } \\
\text { affiliated companies for } \\
\text { the period of } 1998 \text { and } \\
1999 . \text { The affiliation hire } \\
\text { encompasses officers and } \\
\text { directors that were } \\
\text { working as partners in the } \\
\text { auditing firm. }\end{array}$ & $\begin{array}{l}\text { signed and unsigned } \\
\text { abnormal accruals are } \\
\text { higher for affiliated rather } \\
\text { non-affiliated. }\end{array}$ \\
\hline Baber et al. (2014) & $\begin{array}{l}\text { Auditor independence: } \\
\text { Earnings response } \\
\text { coefficient }\end{array}$ & $\begin{array}{l}\text { The sample covers } 4072 \\
\text { year-firm observations for } \\
\text { the period of } 1993 \text { to } \\
\text { 2001. The sample covers } \\
\text { different categories of } \\
\text { financial executive } \\
\text { members. }\end{array}$ & $\begin{array}{l}\text { Earnings Response } \\
\text { Coefficients (ERCs) are } \\
\text { negatively associated } \\
\text { with the ACRD, while it } \\
\text { is non-significantly } \\
\text { associated with non } \\
\text { ACRD cases. The finding } \\
\text { revealed that investors } \\
\text { perceive the practise of } \\
\text { ACRD as impairing } \\
\text { auditors' independence. }\end{array}$ \\
\hline
\end{tabular}

\subsubsection{Audit Quality and the Influence Power of Affiliated Hires}

As stated earlier, the literature is full of initiatives that examine the association between affiliated senior managers and audit quality to either endorse or underestimate the pertinent regulations. FRC identified a broader range of the local groups of hires related to ACRD that include "...director ,officer or employee of any entity relevant to an engagement who is in a position to exert direct and significant influence over the preparation of the financial statements or other subject matter information or subject matter of an engagement, has recently been a partner in the firm, a member of the engagement team or another employee or person whose services are at the disposal or under the control of the firm, where such employee or person is a statutory auditor." (Revised ES, 2019:2.40, p.43). Also, according to the UK corporate governance code (2018, P. 18), non-executive directors played a prominent role in monitoring the management and executive 
members' performance to ensure the achievement of agreed-upon objectives. Thus, non-executive members could affect how financial statements are prepared. Consistent with these requirements, our sample covers both executive and non-executive directors who previously provided auditing services to the client firm.

According also to the FRC, "the significance of the self-interest, familiarity and intimidation threats is assessed and normally depends on such factors as... the position that individual has taken at the entity..." (Revised ES, 2019: 2.41, p.43). Thus, the affiliated auditor's position ranks within the client firm have specific implications on audit quality-accordingly, the higher rank, the more its power in affecting the preparation of the financial statement. Our sample covers four job ranks: executive members such as CFOs, Chief Executive Officers (CEOs), controller etc....; directors such as independent director and senior independent director; non-executive independent director and at the same time audit committee members. The paper expects that the higher the rank, the higher its influencing power in enhancing audit quality by mitigating earning management. Therefore, our second hypothesis is stated in the alternative form:

$\mathrm{H}_{2 \mathrm{~b}}$ : The position ranks of affiliated hires are significantly associated with their magnitude in enhancing audit quality by reducing the level of abnormal earning management.

\section{Main Variables, Sample Selection and Model Specification 3.1 Main Variables Definitions}

The aim of the paper is to examine the implication of the ACRD practises on the audit quality within UK companies. ACRD, is the independent variable which represents a dummy variable that equal one if the director, whether executive or non-executive, are previously working in the current or ex-auditing firm/s within the period from 2008 to 2018 in auditing or non-auditing related jobs. Besides, the paper reclassified the ACRD cases into four types subject to the affiliated directors' job ranks in the corporate hierarchy to measure their influence power. Accordingly, the paper utilized four predicator variables ordered from the higher to the lower ranking levels as follows. RANKEXE is a dummy variable that equals to four if the affiliated directors hold executive position, and zero otherwise. RANKDIR is 
a dummy variable that equal to three if the affiliation is related to directors, and zero otherwise. RANKNonDIRAud is dummy variable that equal to two for affiliated non-executive directors and at the same time an audit committee member, and zero otherwise. Finally, RANKNonDIR is a dummy variable that equal to one if the affiliated director is non-executive directors and zero otherwise.

In order to evaluate the effect of ACRD cases and their influence power in the audit quality, the paper employed the accrual earning management as a proxy for the audit quality. the paper utilized Dechow et al.'s (1995) crosssectional version of the Modified Jones model to estimate the discretionary accrual, DisAcc as a proxy for accrual earning management. As argued by Kothari et al (2005), it is important to control for firm performance while measuring discretionary accrual in order to mitigate the mis-speciation and bias in the estimation model and to control for operating performance outliers, thus ROA should be included in discretionary accruals estimation models (Habbash et al., 2013, Al-Haddad \& Whittington, 2019). Accordingly, DisAcc is computed as residuals of the following regression model that is estimated cross-sectionally for each industry-year.

$\frac{T A C C_{i, t}}{T A_{i, t-1}}=\alpha_{0}+\frac{\beta_{1} * 1}{T A_{i, t-1}}+\frac{\beta_{2} * \Delta R E V_{i, t}-\Delta R E C_{i, t}}{T A_{i, t-1}}+\frac{\beta_{3} * P P E_{i, t}}{T A_{i, t-1}}+\beta_{4 * R O A \varepsilon_{i, t-1}+\varepsilon}$

Where:

$T A C C_{, t}$ represent the total accrual which represents the difference between the earnings before extraordinary items and discontinued operations and the operating cash flows in year for firm $_{i}$

$\mathrm{TA}_{\mathrm{i}, \mathrm{t}-1}$ is the total assets in the year $\mathrm{t}_{-1}$, for the firm ${ }_{\mathrm{i}}$;

$\triangle \mathrm{REV}_{\mathrm{i}, \mathrm{t}}$ is the change in sales revenue from year $\mathrm{t}_{\mathrm{t}-1}$ to year $_{\mathrm{t}}$;

$\triangle \mathrm{REC}_{\mathrm{i}, \mathrm{t}}$ is the change in account recievable from year $\mathrm{t}-1$ to year ${ }_{\mathrm{t}}$;

$\mathrm{PPE}_{\mathrm{i}, \mathrm{t}}$ is the gross property plan and equipment in the year $\mathrm{r}_{\mathrm{t}}$ for firmi $\beta_{1}, \beta_{2}, \beta_{3}, \beta_{4}$ are the estimated parameters, and

cit is the estimated residual that represents the proxy for discretionary accruals, DisAcc.

Similar to Habbash et al., 2013 and Al-Haddad \& Whittington, 2019, DisAcc is the absolute value of residuals. Because the insufficiency of the number of observations within the Two-digit codes, the paper utilized the 
One-digit SIC codes to define industries (Al-Haddad \& Whittington, 2019). As argued by sun et al., 2010, managers may incline toward manipulating earnings either upward or downward, thus the absolute value of residuals would capture the mixed effect of earning management. It is expected that directors' affiliation would improve audit quality by mitigating the accrual earning management (Bird et al., 2015). In addition, Rajgopal et al., (2021) argue a negative association between accrual earning management and audit quality.

A set of control variables are utilized in the paper as follows. First, similar to Habbash (2012), Habbash et al. (2013) and Rajgopal et al. (2021), the paper employes LogAT, defined as the natural logarithm of total assets, to control for the variation in companies' size. Al-Haddad and Whittington, (2019) and Bouaziz et al. (2020) argue that the larger size companies are less oriented toward earning management practices related to discretionary accruals. Accordingly, the paper expects a negative coefficient for LogAT. Second, MTB, is utilized to control for companies' growth opportunities. According to Al-Haddad and Whittington, (2019), MTB, denoted as market to book is positively and significantly related to DisAcc. Thus, the paper expects positive and significant coefficient for $M T B$. Third, ROA is utilized as a proxy for companies' profitability. It is computed as the companies' net income scaled by total assets. Bird et al. (2015) reported a negative and significant relationship between companies' profitability and accrual earning management. Fourth, similar to Rajgopal et al. (2021), the paper controlled for companies' financial risk by Lev, which is measured as total liabilities deflated by total asset. Bouaziz et al. (2020) report that the financial leverage is positively associated with discretionary accruals, so the paper predicts a positive co-efficient of Lev. Finally, following Menon and Williams (2004) and Habbash et al. (2013), the paper addes $C F O$, calculated as cash flow from operations deflated by total assets as the fifth control variable in the paper.

\subsection{Sample Selection}

The initial sample includes all companies listed in the UK FTSE100 for the period from 2008 to 2018. Like Liu (2020), the paper eliminated the utility companies, banks, and financial institutions due to their unique financial reporting regulations and requirements. Hence, according to the 
UK Standard Industrial Classification (SIC) ${ }^{1}$ of economic activities, the paper excluded SIC code numbers 46, 49, 60 to 67 and 91 to 99. Besides, the paper eliminated all companies with missing financial and/or ACRD data ending up to 332 UK companies.

Our sample period can be justified as follows. the paper chooses 2008 as the first year of our covered period since the UK legislation prohibits the ACRD practise at the end of $2004^{2}$, and the calculation of earning management's figures requires the consideration of the financial data of the one lagged years. the paper did not consider the years of 2005 and 2006 to enable a buffering period before measuring the impact of such legislation. the paper extended the covered period to the year 2018, which was the most recent year at the time of preparing this paper. Finally, the sample covers 814 company-year observations over the period from 2008 to 2018.

the paper retrieved all financial data, the list of auditors and the work affiliations of board members in each UK FTSE100 company considered in the sample from the S\&P Capital IQ database. the paper manually reviewed the professional background of all directors to identify the ACRD cases subject to specific criteria stemmed from the Revised ES of 2016 and 2019 that are issued by the FRC. In addition, the paper added some relaxation to such criteria to screen broader cases other than those considered by the regulatory bodies. Accordingly, the paper recognizes companies to be engaged in the revolving door practise if one or more of their current executive or non-executive directors are working within the last ten years in their current or prior audit firm. This overarching definition gives me the room to conduct a more comprehensive analysis of this prohibited type of employment.

\subsection{Model Specification}

The main objective of the paper is to examine the effect of ACRD practises on the audit quality in the UK companies. To do so, the paper developed two empirical models as follows. First, following Menon and Williams, (2004), Model A measures the effect of director - auditor affiliations on the accrual earnings management as a proxy of the audit quality. Second, Model $B$, following Bird et al., (2015), investigates the effect of the influential power of the affiliated directors mediated by their position rank on accrual earning management. Both models estimate the main effect of the 
The effect of companies' employment of their ex-auditors on their Audit Quality: Evidence from UK

independent variables by tracking the behaviour of the absolute value of the discretionary accruals estimated by the Kaothari, et al. (2005)' model. Accordingly, as shown in Table II the paper built the following two models as follows.

\section{Table II The Empirical Models and the Variables' Definitions}

\begin{tabular}{|c|c|}
\hline & \\
\hline DisAccit $=\alpha_{0}+\beta$ & ${ }_{1} * A C R D_{i t}+\beta_{2} * L o g T A_{i t}+\beta_{3} * M T B_{i t}+\beta_{4} * R O A_{i t}+\beta_{5} * L e v i t+\beta_{6} * C F O_{i t}+e_{i t}$ \\
\hline & Model B \\
\hline DisAccit $=\alpha_{0}+\beta_{1}$ & 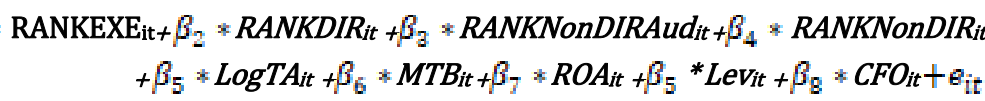 \\
\hline & Dependent Variable \\
\hline DisAccit & is the absolute value of the discretionary accruals for firm in year $_{t}$. \\
\hline & Independent Variables \\
\hline$A C R D_{i t}$ & $\begin{array}{l}\text { Is a dummy variable that equals one if the company has an affiliated } \\
\text { directors in firm }{ }_{i} \text { in year } \text { that are previously working in the former }_{i} \text { that and current auditing firms, and zero otherwise. }\end{array}$ \\
\hline $\mathrm{RANKEXE}_{i t}$ & $\begin{array}{l}\text { is a dummy variable that equals to four if the affiliated directors in firm } \\
\text { for year }{ }_{i} \text { hold executive position, and zero otherwise. }\end{array}$ \\
\hline RANKDIR $_{\text {it }}$ & $\begin{array}{l}\text { is a dummy variable that equal to three if the firm }{ }_{i} \text { in year }_{t} \text { employee an } \\
\text { auditor-affiliation directors, and zero otherwise. }\end{array}$ \\
\hline RANKNonDIRAud $_{i t}$ & $\begin{array}{l}\text { is dummy variable that equal to two if an affiliated non-executive } \\
\text { director and at the same time an audit committee member is working in } \\
\text { the firm }_{\mathrm{i}} \text { in year } \mathrm{t}_{\mathrm{t}} \text {, and zero otherwise. }\end{array}$ \\
\hline RANKNonDIR $_{\text {it }}$ & $\begin{array}{l}\text { is a dummy variable that equal to one if the affiliated director in firmi } \\
\text { for year }{ }_{t} \text { is non-executive directors and, zero otherwise. }\end{array}$ \\
\hline & Control Variable \\
\hline $\operatorname{LogTA}_{\text {it }}$ & Is the natural logarithm of total assets for firm in year $_{t}$. \\
\hline MTB $_{\text {it }}$ & Is the market to book ratio for firm in year $_{t .}$ \\
\hline $\mathbf{R O A}_{\text {it }}$ & $\begin{array}{l}\text { Is the return on assets for firm } \text { in }_{i} \text { year }_{t} \text {, computed as the net income } \\
\text { deflated by the total asset. }\end{array}$ \\
\hline $\operatorname{Lev}_{\text {it }}$ & The total liabilities scaled by total assets for firm in year $_{t}$. \\
\hline $\mathrm{CFO}_{\text {it }}$ & $\begin{array}{l}\text { Is computed as Cash flows from operating activities for } \text { firm }_{i} \text { in year } \\
\text { divided by total assets for year } \\
\text {. }\end{array}$ \\
\hline
\end{tabular}




\section{Empirical Results. 4.1Descriptive Analysis}

Table III shows a summary statistic for the variables used in the regression model. Panel A of Table III presents the descriptive statistics of the continuous variables utilized, namely the mean value, the median, the standard error, and the maximum and minimum value. The descriptive statistics reports the sample mean of DisAcc used as the proxy for discretionary accrual earning management to be 3 per cent where the minimum and maximum absolute residual values are 0 and 5.845633 respectively. The average size of companies' sample, LogTA, is 8.6 ranged from 2 million to 12.7 million. the proxy of firms' growth opportunities, MTB, is scaled around 8.54 with a relatively high standard deviation of 10.6, indicating the wide dispersion in the potential expansion for the sample's companies. The bottom and top values of profitability indicators, ROA is -.9 and 2.5 respectively which implies the variation in the companies' performance over the period. The sample mean of firms' financial leverage, LEV, is 61.8 per cent of the total assets which convey a picture of companies' reliance on debt financing. The average of cash flow from operations to total assets, CFO, is 13 percent.

Panel B of Table III presents the value, the frequency and the percentage of the dummy variables. Almost 15 per cent of non-financial FTSE100 companies are recruiting affiliated directors within the period from 2010 to 2018. Disseminating this ratio of ACRD cases according to the influential power of affiliated directors reveals that the highest frequency recruitment of affiliated directors is associated with directors in executive position, $R A N K E X E$, with nearly 5 percent. In addition, a relatively approachable ratios for the following position ranks of affiliated directors, namely RANKDIR and RANKNonDIRAud with frequency ratio of 5 percent and 6 per cent respectively. The lowest repeated affiliation is related to RANKNonDIR which yields nearly 2 per cent of the total ACRD cases. Accordingly, the tendency of the ACRD cases subject to their position ranks demonstrates a downward trend, that is the higher the rank of the affiliated director, the lower its prevalence within UK companies.

Panel $\mathrm{C}$ of Table III shows the trends of ACRD cases within UK companies for the period from 2010 to 2018. The number of ACRD cases 
The effect of companies' employment of their ex-auditors on their Audit Quality: Evidence from UK

shows upward bent over the examined period beginning from only three cases in 2010 to seventeen cases in 2018. This implies that the auditing experience hold by affiliated directors may provide them with competitive qualifications in the marketplace.

\section{Table III The Descriptive Statistics}

\begin{tabular}{|c|c|c|c|c|c|c|c|c|c|c|c|c|}
\hline \multicolumn{13}{|c|}{ Panel A: Summary Statistics for Continuous Variables } \\
\hline & & & Obs & \multicolumn{2}{|c|}{ Mean } & \multicolumn{2}{|c|}{ Std. Dev. } & \multicolumn{2}{|c|}{ Min } & \multicolumn{3}{|c|}{ Max } \\
\hline \multicolumn{3}{|c|}{ DisAcc } & 814 & \multicolumn{2}{|c|}{.304} & \multicolumn{2}{|c|}{.506} & \multicolumn{2}{|c|}{$\mathbf{0}$} & \multicolumn{3}{|c|}{5.85} \\
\hline \multicolumn{3}{|c|}{ LogTA } & 814 & \multicolumn{2}{|c|}{8.585} & \multicolumn{2}{|c|}{1.726} & \multicolumn{2}{|c|}{1.96} & \multicolumn{3}{|c|}{12.72} \\
\hline \multicolumn{3}{|c|}{ MTB } & $\mathbf{8 1 4}$ & \multicolumn{2}{|c|}{8.542} & \multicolumn{2}{|c|}{10.689} & \multicolumn{2}{|c|}{-133.79} & \multicolumn{3}{|c|}{232.65} \\
\hline \multicolumn{3}{|c|}{ ROA } & 814 & \multicolumn{2}{|c|}{.083} & \multicolumn{2}{|c|}{.216} & \multicolumn{2}{|c|}{-.900} & \multicolumn{3}{|c|}{2.52} \\
\hline \multicolumn{3}{|c|}{ Lev } & 814 & \multicolumn{2}{|c|}{.619} & \multicolumn{2}{|c|}{.268} & \multicolumn{2}{|c|}{.026} & \multicolumn{3}{|c|}{2.83} \\
\hline & CFO & & $\mathbf{8 1 4}$ & & 30 & & & -.1 & & & 2.63 & \\
\hline & & & Pan & B: Sun & mary $S$ & tistics & or Dum & ay Varia & bles & & & \\
\hline & Variable & & Obs & & lue & Freq & iency & & & Percent & & \\
\hline & ACRD & & 814 & & ) & & & & & 85.38 & & \\
\hline & & & & & 1 & & & & & 14.62 & & \\
\hline & RANKEX & & 814 & & ) & & & & & 94.96 & & \\
\hline & & & & & 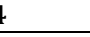 & & & & & 5.04 & & \\
\hline & RANKDI & & 814 & & ) & & & & & 95.1 & & \\
\hline & & & & & 3 & & & & & 4.9 & & \\
\hline RANI & KNonDI & Aud & 814 & & ) & & & & & 94.23 & & \\
\hline & & & & & 2 & & & & & 5.77 & & \\
\hline & NKNon & & 814 & & 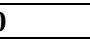 & & & & & 98.65 & & \\
\hline & & & & & I & & & & & 1.35 & & \\
\hline & & Pan & I C: The & Trend c & f ACRD & rom 20 & 0 to 20 & 8 for UK & comp & nies & & \\
\hline ACRD & 2008 & 2009 & 2010 & 2011 & 2012 & 2013 & 2014 & 2015 & 2016 & 2017 & 2018 & Total \\
\hline 0 & 71 & 71 & 69 & 66 & 64 & 61 & 61 & 59 & 57 & 59 & 57 & 695 \\
\hline 1 & 3 & 3 & 5 & 8 & 10 & 13 & 13 & 15 & 17 & 15 & 17 & 119 \\
\hline Total & 74 & 74 & 74 & 74 & 74 & 74 & 74 & 74 & 74 & 74 & 74 & 814 \\
\hline
\end{tabular}

\subsection{Correlation Matrix}

Table IV presents the correlation matrix for the independent variables. The correlation between independent variables should be less than 0.8 to indicate the inexistences of multicollinearity problems among variables (Pucheta- Martínez and Gallego- Álvarez, 2019 and Bouaziz et al.,2020). Accordingly, as shown in Panel A, Table IV, as long as none of the 
correlation coefficients shows a value greater than 0.8 , there is no multicollinearity problems in the regression model.

\section{Table IV The Correlation Results}

\begin{tabular}{|c|c|c|c|c|c|c|c|c|}
\hline \multirow[b]{2}{*}{ Variable } & \multicolumn{6}{|c|}{ Panel A: Correlation Matrix } & \multicolumn{2}{|c|}{ Panel B: VIF } \\
\hline & ACRD & LogTA & MTB & ROA & Lev & CFO & VIF & Tolerance \\
\hline ACRD & 1.0000 & & & & & & 1.05 & 0.953573 \\
\hline LogTA & $\begin{array}{l}0.0174 \\
0.6193\end{array}$ & 1.0000 & & & & & 1.17 & 0.855211 \\
\hline MTB & $\begin{array}{l}0.0681^{*} \\
0.0519\end{array}$ & $\begin{array}{l}-0.0896^{\star} \\
0.0055\end{array}$ & 1.0000 & & & & 1.15 & 0.86869 \\
\hline ROA & $\begin{array}{l}0.1843^{\star} \\
0.0000\end{array}$ & $\begin{array}{l}-0.2386^{\star} \\
0.0000\end{array}$ & $\begin{array}{l}0.3249^{\star} \\
0.0000\end{array}$ & 1.0000 & & & 3.27 & 0.305496 \\
\hline Lev & $\begin{array}{l}-0.0919^{\star} \\
0.0086\end{array}$ & $\begin{array}{l}-0.0318 \\
0.3257\end{array}$ & $\begin{array}{l}0.0481 \\
0.1363\end{array}$ & $\begin{array}{l}-0.0709^{\star} \\
0.0281\end{array}$ & 1.0000 & & 3.81 & 0.262366 \\
\hline CFO & $\begin{array}{l}0.1647^{\star} \\
0.0000\end{array}$ & $\begin{array}{l}-0.3136^{*} \\
0.0000\end{array}$ & $\begin{array}{l}0.3520^{*} \\
0.0000\end{array}$ & $\begin{array}{l}0.6930^{*} \\
0.0000\end{array}$ & $\begin{array}{l}0.0612^{\star} \\
0.0581\end{array}$ & 1.000 & 2.71 & 0.367930 \\
\hline
\end{tabular}

As additional evidence that there is no multicollinearity problem among the independent variables, the paper employed the Variance Inflation Factor (VIF) matrix as shown in Table IV, Panel B. According to Bager (2017), VIF needs to be less than 10 and tolerance level needs to be more than 0.2 to indicate that there is no linear correlation among variables. The VIF results displayed in Table IV, Panel B reveals that the VIFs for all variables are ranged from 1.05 and 3.81, below than ten and the tolerance level are above 0.2 for all variables.

\section{3 Regression Results}

In order to identify the appropriate panel estimation model, the paper employed the Hausman specification test to be able to choose between fixed and random effects for the two model. According to Park (2011), if the null hypothesis that denotes those individual effects are not correlated with the independent variable is not rejected, then the random effect is favourable than fixed effect model. As shown in Table V, the results for Hausman test shows that the probability value of null hypothesis for model $\mathrm{A}$ is 0.066 and for model B is 0.175 are both larger than $5 \%$, the significance level, thus the 
paper could not reject the null hypothesis, and the paper utilized random rather than fixed effect regression model.

\section{Table V Results of Hausman Test}

\begin{tabular}{|l|l|l|}
\hline \multicolumn{2}{|l|}{ Specification Test: Hausman Test } \\
\hline & Model A & Model B \\
\hline Chi2(6) & 11.82 & 12.74 \\
\hline Prob>chi2 & 0.066 & 0.175 \\
\hline
\end{tabular}

Table VI shows the results of the regression analysis for both models utilized in the paper. Model A's column in Table VI shows the results of the regression estimation for the effect of the director-auditor affiliations on the audit quality where the independent variable is $A C R D$. The p-value of the model is 0.02 which is lower than 0.05 significance threshold, implying that the model is correctly specified. Model A in Table VI shows that the relationship between $A C R D$ and DiaAcc is significant and negative at significance level of 0.05 where $\beta_{1}=-.193$ and $\mathrm{p}$-value $=0.001$, thus $\mathrm{H}_{1}$ is accepted. This implies that the level of the absolute discretionary accruals would by decreased by 2 percent for affiliated companies, that is hiring directors with working experience in the current or ex auditing company. The results are consistent with Geiger, et al. (2005) who indicate that that companies that hire affiliated executive directors directly for their audit companies do not report higher levels of accounting accruals. The results also are in accordant with Bird et al., (2015) who report that an increase in the ratio of the affiliated accounting employees to the total number of accounting employees in a company by 1 percent would yields, on average, 0.4 percent decrease in absolute abnormal accruals deflated by average total assets.

The results are in conflicting with the results of Lennox (2005). As argued by Geiger, et al. (2005), although the findings of Lennox (2005) are in harmony with regulatory concern toward the negative implications of ACRD on audit quality; these findings are highly significant for cases of alma mater affiliations more than for ACRD. Moreover, research papers such as Geiger et al., (2008) and Baber et al. (2014), which precisely measure the effect of ACRD on earnings management, could not find any 
change in the level of absolute discretionary accruals between companies with and without ACRD. Furthermore, Naiker and Sharma (2009) study the impact of the appointment of affiliated and non-affiliated auditor in the audit committee on the effectiveness of internal control over financial reporting. Their results revealed no significant difference between affiliated and nonaffiliated auditors' presence and the disclosure of internal control weakness in financial reporting. Both affiliated and non-affiliated auditors are negatively associated with the extent of detecting internal control deficiencies suggesting that SOX three-years restriction of affiliated auditor to be appointed in audit committee is not boosting the monitoring role of the committee over internal control (Naiker and Sharma, 2009).

The results may not be compatible with the regulatory bodies concerns in UK regarding the probable impairment of audit quality as the result of ACRD practise. A possible justification could be driven from the argument that when strong regulations constrain mangers' access to manipulate earning through accrual-based activities, they will engage in certain real activities manipulation to maintain earning targets (Cohen et al. 2008; and Ho et al., 2015). It is debated that accounting standards and regulations tangle the route toward accrual earning management while hanging around real manipulation of activities, although the unfavourable impacts accompany such activities on future cash flows that is by imposing a real cost to the firm in the long run (Ewert and Wagenhofer, 2005, Cohen et al. 2008, Chi et al., 2011).

A stream of research provides ample evidence that managers are more engaged in real, rather accrual-based earning management after the passage of SOX and other similar regulations. Cohen et al., 2008 report that companies are extravagantly resorting to real earning management after SOX in the manner that implies that such companies are substituting their practice of earning management from accrual to real to avoid "auditors" or regulators' scrutiny while maintaining earning target. Cohen and Zarowin (2010) argue that managers are more likely to be involved in earning management through real activities than accrual-based earning management because it is difficult to be revealed by auditors. Among other findings, Chi et al., 2011 highlight the importance of imposing mandatory regulation for partner rotation because of the significant association between the longer 
The effect of companies' employment of their ex-auditors on their Audit Quality: Evidence from UK

duration of the auditor-client relationship and the higher levels of real earning management.

Table VI The Regression Result

\begin{tabular}{|l|l|l|l|l|}
\hline & \multicolumn{2}{|c|}{ Model A } & \multicolumn{2}{c|}{ Model B } \\
\hline Independent Variables & Co-efficient & p-value & Co-efficient & .p-value \\
\hline ACRD & -.1931313 & 0.001 & & \\
\hline RANKEXE & & & -.01578 & 0.527 \\
\hline RANKDIR & & & -.0443539 & 0.285 \\
\hline RANKNonDIRAud & & & -.1749753 & 0.000 \\
\hline RANKNonDIR & \multicolumn{5}{|l|}{} \\
\hline \multicolumn{5}{|c|}{ Control variables } \\
\hline LogTA & -.0138048 & 0.535 & -.1417485 & 0.412 \\
\hline MTB & 3.06006 & 0.023 & -.0183631 & 0.387 \\
\hline ROA & .0179294 & 0.090 & .0281414 & 0.050 \\
\hline Lev & .0442249 & 0.640 & .079466 & 0.876 \\
\hline CFO & -.0719345 & 0.739 & -.0832323 & 0.685 \\
\hline \multicolumn{5}{|l|}{} \\
\hline P-value & 0.02 & & 0.02 & \\
\hline R-sq (overall) & 0.01 & & 0.002 & \\
\hline $\mathrm{N}$ & 814 & 814 & \\
\hline
\end{tabular}

Table VI, Model B's column display the regression results related to the effect of the different positional ranks of affiliated directors, namely RANKEXE; RANKDIR; RANKNonDIRAud and RANKNonDIR on the audit quality. The model is correctly specified since the p-value of model $\mathrm{B}$ equal to 0.02 , which are less than 0.05 significance threshold. Table VI, Model B's column shows also the direction and the significance level of the association between the different positional ranks of affiliated directors subject to their corporate hierarchal level and audit quality. The results fail to find any significant association between RANKEXE; RANKDIR and RANKNonDIR and audit quality, measured as absolute discretionary accrual at significance level of 0.05 , where p-value are equal to 0.527 , 0.285 and 0.412 respectively. However, the results only revealed a negative and significant relationship between affiliated non-executive directors that 
are members in the audit quality and the level of absolute discretionary accrual at significance threshold of 0.05 where $\beta_{3=-.17}$ and $\mathrm{p}$-value $=0.00$. Taken altogether, the results generally do not support the argument that the positional ranks of affiliated directors affect the audit quality, except for non-executive directors belongs to audit committee. Thus, the paper fails to accept $\mathrm{H}_{2}$. The results are then harmony to Bird et al. (2015) who argued that only affiliated accounting employees at the lower hierarchal levels such as accounting analyst and senior accountant could participate in enhancing the audit quality levels as evident by their accompanied level of lower likelihood of financial misstatement and absolute abnormal accruals. Also, Dowdell and Krishnan (2004) fail to recognize any variation in the level of absolute discretionary accruals between companies with affiliated and nonaffiliated directors at executive level.

The results imply that the auditor- affiliation directors at the executive and non-executive levels may not affect the level of reported accrual earning management in UK companies, except for non-executive directors belongs to audit committees. This result may be justified by the role of the audit committee as strong governance mechanism that may restrain the accrual earning management practises. Audit Committee is recognized as internal governance mechanism committed to supervise, control and assist management in executing robust internal control, presenting fair financial reporting and monitoring the auditing process (Beasley et al., 2009; Sun et al., 2011; Oussii et al., 2019; and Guidelines of Board Effectiveness,2018, Provision 117, p.31). In addition, as argued by Velte, 2018, audit committee members are pursuing strong external auditing since external auditors assist their oversighting role. Accordingly, non-executive directors that are acting as an audit committee's member are in position that enable them to utilize their previous interrelationships with the audit firm, to benefit from their former auditing experience in the manner that may positively contribute to the audit quality at overall.

Table VI also shows the results related to the control variables. Similar to the expectation, the relationship between LogTA and DisAcc is negative in both models where $\beta_{2}=-.014$ in model $\mathrm{A}$ and $\beta_{5}=-.018$ in model $\mathrm{B}$. However, the p-value for LogTA is insignificant in both models at significance level of 0.05 . In addition, similar also to the prediction, MTB 
have positive co-efficient in both models where $\beta_{3}=3.06$ in model $\mathrm{A}$ and $\beta_{6}=0.023$ in model $\mathrm{B}$ and significant at significance level 0.05 since $\mathrm{p}$ value equal to 0.023 and 0.050 in model $A$ and $B$ respectively. the paper fails to find any association between ROA and DisAcc in both models at significance level of 0.05 . Contrary to the expectation, Lev is negative and non-significant at significance level of 0.05 in both models. Finally, CFO is also negative and insignificant in both models at significance level of 0.05 where p-value equals to 0.739 for model A and to 0.685 for model B. Similarly, Menon and Williams, (2004) reported a negative co-efficient for CFO in its effect on DisAcc.

\subsection{Additional Test: The Cooling off Period}

Although the regulatory bodies emphasise the importance of the cooling-off period in enhancing auditor independence and in turn the audit quality, there is a slight variation around the time frame of such period across countries. While SOX mandated a one-year cooling-off period before former auditing partners can join USA public companies in financial reporting function, Australia and the UK instead impose two years cooling period (Basioudis, 2007). Furthermore, there is disagreement regarding whether it is necessary to impose the cooling off from the outset at the academic level. In this regard, two sparse groups are found, as shown in Table VII. The first group indicate the significance of the cooling-off period. Wright and Booker (2010) indicated that the state board of accountancy' members accentuate the importance of a one-year cooling-off period in boosting the level of auditors' independence. Nevertheless, extending the cooling-off period from one to two years does not add value to their perceptions toward auditors' independence (Wright and Booker, 2010). In a similar vein, Abbott et al. (2016) examined the role of a 13-months cooling-off period in mitigating the concerns of audit committee members toward the unfavourable consequence of ACRD of impairing auditors' independence and found that the length of the cooling-off period is not enough to extenuate the concerns of audit committee members. Furthermore, Abbott et al. (2016) called for further research that investigates how long the ideal cooling-off period needs to be. 


\section{Table VII Contradicted Results Related to Cooling-off Period}

\begin{tabular}{|c|c|c|}
\hline \multirow{2}{*}{$\begin{array}{l}\text { The argument that } \\
\text { cooling-off period is } \\
\text { necessary to enhance } \\
\text { auditors' } \\
\text { independence that } \\
\text { might be impaired due } \\
\text { to ACRD practice. }\end{array}$} & $\begin{array}{l}\text { Wright and } \\
\text { Booker, } 2010\end{array}$ & $\begin{array}{l}\text { Their findings indicate the importance of } \\
\text { one-year rather than two-years cooling off } \\
\text { period in improving the realization toward } \\
\text { auditors' independence. }\end{array}$ \\
\hline & ,2016 & $\begin{array}{l}\text { Their findings reveal that cooling-off period } \\
\text { of 13-monthes provides little assistance } \\
\text { toward capturing the concerns of audit } \\
\text { committee member toward impairing } \\
\text { auditors' independence as result of ACRD. }\end{array}$ \\
\hline \multirow{3}{*}{$\begin{array}{l}\text { The argument that the } \\
\text { cooling-off period is } \\
\text { not necessary and } \\
\text { regulatory bodies } \\
\text { need to revisit such } \\
\text { restriction. }\end{array}$} & $\begin{array}{l}\text { Geiger et } \\
2005,2008\end{array}$ & $\begin{array}{l}\text { They explicitly stated the insignificance of } \\
\text { SOX restriction of ACRD in protecting } \\
\text { shareholders. }\end{array}$ \\
\hline & $\begin{array}{l}\text { Naiker and } \\
\text { Sharma, } 2009\end{array}$ & $\begin{array}{l}\text { They indicate that cooling-off period are } \\
\text { "counter to" the original purpose of SOX of } \\
\text { enhancing audit quality. }\end{array}$ \\
\hline &., 2013 & $\begin{array}{l}\text { ling } \\
\text { ce. }\end{array}$ \\
\hline
\end{tabular}

On the other hand, the second group undervalues the significance of the cooling-off period and induces regulatory bodies to revisit such restriction. Geiger et al. (2008) indicate that the market positively interacts with the practices of ACRD. Thus, SOX's mandatory restriction to such practices may not be necessary and may not add value to shareholders. Furthermore, Naiker and Sharma, 2009 indicate that the cooling-off period might impair rather than enhancing auditing quality because it entails scarifying years of considerable experience of former auditor partners until they are permitted to join the client firm. Also, Naiker and Sharma (2009) recommend that the regulators revisit the cooling-off period for further improvement. Naiker et al. (2013) argue that it is not guaranteed that a cooling-off period is sufficient to remove the regulatory concerns toward impairing auditors' independence as the result of ACRD, that is because the power of social and long-term relations entailed by affiliation may be much efficacious.

As stated earlier, FRC mandated a two-years cooling period before the former auditor or any member of the audit engagement could be hired in a managerial position within the client firm, and a one-year in any other cases (Revised ES, 2019:2.43, p.44). The FRC explicitly states their concerns toward impairing the auditors' independence and audit quality as the result 
of the revolving door practice as follows: "Should a partner or other covered person join an entity relevant to an engagement, threats to integrity, objectivity and independence may arise that a firm will need to address. Such threats may also exist where a former partner or other covered person is employed by an entity that the firm is considering accepting an engagement for." (Revised ES, 2019:2.44, p.44).

The FRC mandates a buffering period of two years before the audit engagement team could join the client firm to ensure the alleviation of "the self-interest, familiarity and intimidation threats" (Revised ES, 2019:2.41, p.43). The aim is to identify whether such concerns of the UK regulatory bodies toward the revolving door practise are handled or not by mandating the cooling off period. Thus, the paper tried to measure the average change in the absolute discretionary accrual, DisAcc after the affiliated directors joined the client firm to figure out whether the cooling off period acted its alleged role. To do so, the paper used a Differences- in- Differences (DiD) pooled cross sectional analysis. According to Wooldridge (2013, p.465), $\mathrm{DiD}$ pooled cross sectional analysis is suitable when it is required to track the effect of certain event or treatment on the average outcome of the independent variable over two time slots, that is before and after the treatment. Accordingly, the aim is to assess the effect of the cooling off period on the audit quality in which companies with ACRD is considered the treatment group and companies with non-ACRD are the control group. The DiD calculates the effect of the audit-affiliations hold by companies' directors on the level of absolute discretionary accruals or DisAcc by comparing the average change of DisAcc before and after the cooling-off period for ACRD companies, compared to the average change for the nonACRD companies.

As shown in Table IX the coefficient for $D i D$ is negative and insignificant at 0.05 significance threshold since $\mathrm{p}$-value $=0.121$, suggesting thqt it is possible to detect a reduction in average change of the DisAcc over the sample period time between ACRD and non-ACRD companies. Accordingly, the cooling-off period is necessary to wipe out any adverse consequences that may be accompanied with revolving door practise and it ensure the overweigh of the affiliated directors' expertise and relationships over the undesirable effect of earning management manipulation. Wright 
and Booker (2010) indicate the importance of cooling off period since it is perceived by the State board of accountancy's members as an important sign of the independence of the audit firm that provide auditing services to one of its client with affiliated directors that were its former CPAs or audit managers.

\section{Table IX Results of Difference-in Differences (DiD) Estimation}

\begin{tabular}{|c|c|c|}
\hline \multicolumn{2}{|c|}{ Panel A: Estimating DiD } & p-value \\
\hline Before & & \\
\hline Control & -14.06 & \\
\hline Treated & -2.63 & \\
\hline Diff & 11.42 & .429 \\
\hline After & & \\
\hline Control & -14.05 & \\
\hline Treated & -2.6 & .429 \\
\hline Diff & 11.42 & 0.121 \\
\hline DiD & -.1887944 & \\
\hline
\end{tabular}

\section{Conclusion}

The finding reveals that the practise of hiring director that are previously affiliated in the auditing firm enhance the audit quality for UK companies as evident by the decrease in the absolute discretionary accrual. In addition, the findings indicate the positional rank of the affiliated hire has no impact in the audit quality, with the only exception related to affiliated non-executive directors in the audit committee. That is, from one set, their position enables them to exert strong oversight and scrutiny over external auditing. And from the other set, their former affiliation and experience facilitate the auditing process in the manner that enhance the auditing quality at overall. In addition, the findings reveal that the cooling off period may be a practical solution to mitigate any unfavourable consequences of ACRD claimed by the regulators since the paper could not find any differences in the change of discretionary accrual earning management between affiliated and nonaffiliated companies.

The results have certain implications for the regulatory bodies, companies' boards and audit firms. First, it directs the attention of the regulators in UK to the importance of the auditing revolving door practise since it is 
associated with positive effect on the audit quality. The ACRD hires enable companies' boards for utilizing the auditing experience and relational powers of the affiliated directors that may lighten or faded overtime. Second, it enhances the perceptions toward the potential consequence of board members-affiliations in such these former affiliations could play governance role in restraining, rather than boosting the management' earning management practices. That is because the synergies positive effect of affiliated auditors either because of their social interrelationships with the audit engagement team or because their previous experience and knowledge in the client firm and industry, in general, would enhance the process of financial reporting, and hence the quality of auditing process. Third, it also clarifies the perception toward the revolving doors' threats of auditor's independence formerly alleged by the regulators. Fourth, it indicates that the cooling off period has essential role in wiping out the regulatory bodies' concerns toward the revolving door bad consequences effect.

The limitations of the paper provide avenues for future research. First, the literature reveals different measures for audit quality, it would be interesting if other researchers measure the association between the ACRD hires and audit quality proxied by other measures. In this regard, Rajgopal et al. (2021) utilizes other fourteen commonly used measures. Second, while the notion of REM involves mangers' intention to choose the alternative of actions and decisions other than optimal to meet earning targets, the ARM is related to the mechanism at which accounting standards are employed to report certain transactions (Ewert and Wagenhofer, 2005). In the same line, Zang (2012) distinguishe between real activities manipulation, which entails altering the timing and the format of real transactions and accrual earning management related to the transition of the accounting estimates and methods accompanied by certain transactions presented in the financial statement. It argues that both angles of earning management practices are working as substitutes; when strong regulations constrain mangers' access to manipulate earning through accrual-based activities, they will engage in certain real activities manipulation to maintain earning targets (Cohen et al. 2008; and Ho et al., 2015). Accordingly, it would be entrancing if other papers examine the implications of ACRD corresponding to the substitutional relationship between REM and AEM. Finally, the results are 
valid for UK FTSE100 companies, thus, to gain more insights and to ensure popularity of findings, it would be better to expand the sample to cover FTSE350 companies or even all listed UK companies.

\section{Notes}

1 Please refer: https://www.gov.uk/government/publications/standard-industrialclassification-of-economic-activities-sic

2 As mentioned earlier, the UK Auditing Practices Board (APB) issued five ethical standards (ESs) that cover issues related to "the integrity, objectivity and independence for auditors", effective beginning from 14 December 2004. For further details, please refer to https://www.icaew.com/technical/ethics/auditor-independence/independence-guidance

\section{Reference}

Abbott, Lawrence J.; Brown, Veena L. and Higgs, Julia L. (2016) "The Effects of Prior Manager-Auditor Affiliation and PCAOB Inspection Reports on Audit Committee Members' Auditor Recommendations". Behavioural Research in Accounting. 28(1). Spring ,pp. 1-14.

Al-Haddad, Lara and Whittington, Mark (2019) "The Impact of Corporate Governance Mechanisms on Real and Accrual Earnings Management Practices: Evidence from Jordan”, Corporate Governance. 19 (6), 2019, pp. 1167-1186,

Baber, William R.; Krishnan, Jagan and Zhang, Y. (2014) "Investor Perceptions of The Earnings Quality Consequences of Hiring an Affiliated Auditor", Review of Accounting Studies, 19(1), pp. 69-102.

Bager, Ali; Roman, Monica; Algelidh, Meshal and Mohammed, Bahr (2017) "Addressing Multicollinearity in Regression Models: A Ridge Regression Application.", Journal of social and Economic Statistics, 6 (1), Summer, pp.2-45.

Basioudis, Ilias G. (2007) “Auditor's Engagement Risk and Audit Fees: The Role of Audit Firm Alumni”, Journal of Business Finance \& Accounting, November/December,34(9\&10), pp.1393-1422, doi: 10.1111/j.14685957.2007.02052.x

Beasley, M.S., Carcello, J.V., Hermanson, D.R. and Neal, T.L. (2009), "The audit committee oversight process", Contemporary Accounting Research, 26 (1), pp. 65-122. 
Bird, Andrew; Ho,Nam; Li, Chan and Ruchti, Thomas G. (2015)"That's What Friends are for: Audit Quality and Accounting Employee Affiliations with Audit Firms", SSRN Electronic Journal, January https://papers.ssrn.com/sol3/papers.cfm?abstract_id=2659700

Bouaziz,D., Salhi, B. and Jarboui, A. (2020), "CEO Characteristics and Earnings Management: Empirical Evidence From France", Journal of Financial Reporting and Accounting, 18(1), pp.77-11.

Chi, W., Lisic, L., and Pevzner, M. (2011) "Is Enhanced Audit Quality Associated with Greater Real Earnings Management?", Accounting Horizons, 25(2), pp. 315-335.

Cohen, D., A. Dey, and T. Lys. (2008) "Real and Accrual-Based Earnings Management in The Pre- and Post-Sarbanes-Oxley Periods", The Accounting Review, 83(3), pp. 757-787.

Cohen, D., and P. Zarowin (2010) "Accrual-based and real earnings management activities around seasoned equity offerings", Journal of Accounting and Economics, 50(1), pp. 2-19.

Dart, E., \& Chandler, R. (2013). Client employment of previous auditors: Shareholders' views on auditor independence. Accounting and Business Research, 43(3), 205-224.

DeAngelo, Linda Elizabeth (1981)" Auditor Size and Audit Quality", Journal of Accounting and Economics, 3(3), pp. 183-199, ISSN 0165-4101, https://doi.org/10.1016/0165-4101(81)90002-1.

Dechow, Patricia M; Sloan, Richard G and Sweeney, Amy P. (1995) "Detecting Earnings Management", Accounting Review, 70(2), pp.193225.

Doukakis,Leonidas C. (2014) "The Effect of Mandatory IFRS Adoption On Real and Accrual-Based Earnings Management Activities", Journal of Accounting and Public Policy,33(6), pp. 551-572,ISSN 02784254,https://doi.org/10.1016/j.jaccpubpol.2014.08.006. 
Dowdell, T. D., and J. Krishnan (2004) "Former Audit Firm Personnel as CFOs: Effects on earnings Management", Canadian Accounting Perspectives, 3(1), pp. 117-142.

Ewert, R., and A. Wagenhofer (2005) "Economic Effects of Tightening Accounting Standards to Restrict Earnings Management", The Accounting Review, 80(4), pp.1101-1125.

Ferguson, A., J. Francis, and D. Stokes (2003) "The Effects of Firm-Wide and Office-Level Industry Expertise on Audit Pricing", The Accounting Review, 78(2), pp. 429-448.

Frankel, R.M., M.F. Johnson, and K.K. Nelson. 2002. The relation between auditors' fees for non-audit services and earnings management., The Accounting Review, 77 (s-1),pp. 71-105.

Geiger, M. A., D. S. North, and B. T. O'Connell (2005) "The Auditor-ToClient Revolving Door and Earnings Management", Journal of Accounting, Auditing \& Finance, 20(1), pp. 1-26.

Geiger, M. A.,, C. S. Lennox, and D. S. North (2008) "The Hiring of Accounting and Finance Officers From Audit Firms: How Did The Market React?", Review of Accounting Studies, 13, (1), pp.55-86.

Guidance on Board Effectiveness

https://www.frc.org.uk/getattachment/61232f60-a338-471b-ba5abfed25219147/2018-Guidance-on-Board-Effectiveness-FINAL.PDF

Habbash, Murya; Sindezingue, Christoph and Salama, Aly (2013) "The Effect of Audit Committee Characteristics on Earnings Management: Evidence from The United Kingdom”, International Journal of Disclosure and Governance, 10, pp. 13-38.

Ho, Li- Chin Jennifer; Liao, Qunfeng and Taylor, Martin (2015) "Real and Accrual- Based Earnings Management in the Pre- and Post- IFRS Periods: Evidence from China", Journal of International Financial Management \& Accounting, 26 (3), October, pp. 294-335 https://doi.org/10.1111/jifm.12030. 
Hofstede , G . ( 2001 ) Culture's Consequences: Comparing Values, Behaviours, Institutions, and Organizations Across Nations , 2nd edn. Thousand Oaks, CA: Sage Publications.

Kothari, S.P., Leone, A. and Wasley, C. (2005), "Performance matched discretionary accrual measures", Journal of Accounting and Economics, 39 (1), pp. 163-197.

Lennox, C. (2005) “Audit Quality and Executive Officers' Affiliations with CPA firms", Journal of Accounting and Economics, 39(2), pp. 201-231.

Lennox, C. and C. Park (2007) "Audit Firm Appointments, Audit Firm Alumni, And Audit Committee Independence", Contemporary Accounting Research, 24(1), pp.235-258.

Liu, Min (2020) "Real and Accrual-Based Earnings Management in the Pre-and Post- Engagement Partner Signature Requirement Periods in the United Kingdom", Review of Quantitative Finance and Accounting, Springer. 54(3), April, pp.1133-1161 https://doi.org/10.1007/s11156-01900827-2

Menon, K., and D. D. Williams (2004) "Former Audit Partners and Abnormal Accruals", The Accounting Review, 79 (4), pp.1095-1118.

Naiker, Vic and Sharma, Divesh S. (2009) "Former Audit Partners on the Audit Committee and Internal Control Deficiencies", The Accounting Review, 84 (2), pp. 559-587. DOI: 10.2308/accr.2009.84.2.559

Naiker,Vic; Sharma, Divesh S. and Sharma, Vineeta D. (2013) "Do Former Audit Firm Partners on Audit Committees Procure Greater Nonaudit Services from the Auditor?", The Accounting Review, 88(1), pp.297-326 https://doi.org/10.2308/accr-50271

Oussii, Ahmed Atef; Klibi, Mohamed Faker and Ouertani, Insaf (2019) "Audit Committee Role: Formal Rituals or Effective Oversight Process?", Managerial Auditing Journal, 34(6), pp. 673-695. DOI 10.1108/MAJ-112017-1708.

Park, H. M. (2011), "Practical Guides to Panel Data Modelling: A Step-bystep Analysis Using Stata", Tutorial Working Paper-Graduate School of 
International Relations, International University of Japan, https://www.iuj.ac.jp/faculty/kucc625/method/panel/panel_iuj.pdf Pucheta-Martínez, M. C., and Gallego-Álvarez, I. (2019), “An International Approach of The Relationship Between Board Attributes and The Disclosure of Corporate Social Responsibility Issues", Corporate Social Responsibility and Environmental Management, 26(3), pp.612-627.

Revised ES (2016) "Part B, Section two, Financial, Business, Employment and Personal Relationship", Financial Reporting Council, Revised Ethical Standard (ES), https://www.frc.org.uk/getattachment/0bd6ee4e-075c-4b55a4ad-b8e5037b56c6/Revised-Ethical-Standard-2016-UK.pdf

Revised ES (2019) "Part B, Section two, Financial, Business, Employment and Personal Relationship", Financial Reporting Council, Revised Ethical Standard (ES), https://www.frc.org.uk/getattachment/601c8b09-2c0a-4a6c8080-30f63e50b4a2/Revised-Ethical-Standard-2019-With-Covers.pdf

Sitanggang, R.P., Karbhari, Y., Matemilola, B.T. and Ariff, M. (2019), "Audit quality and real earnings management: evidence from the UK manufacturing sector", International Journal of Managerial Finance, 16 (2), pp. 165-181. https://doi.org/10.1108/IJMF-03-2018-0095

Sun , N . , Salama , A ., Hussainey , K . and Habbash , M .( 2010 ) "Corporate Environmental Disclosure, Corporate Governance And Earnings Management”. Managerial Auditing Journal 25 (7), pp.679 - 700.

Sun, Jerry; Liu, Guoping and Lan, George (2011) "Does Female Directorship on Independent Audit Committees Constrain Earnings Management?", Journal of Business Ethics, 99, pp. 99:369-382.DOI 10.1007/s10551-010-0657-0.

Tepalagul, Nopmanee and Lin, Ling (2015) "Auditor Independence and Audit Quality: A Literature Review", Journal of Accounting, Auditing \& Finance, 30 (1), pp.101-121. DOI: 10.1177/0148558X14544505
UK Corporate
Governance
(CG)
Code
(2018)
at

https://www.frc.org.uk/getattachment/88bd8c45-50ea-4841-95b0d2f4f48069a2/2018-UK-Corporate-Governance-Code-FINAL.PDF 
Velte, P. (2018), "Does gender diversity in the audit committee influence key audit matters' readability in the audit report? UK Evidence", Corporate Social Responsibility and Environmental Management, 25(4), pp. 748-755.

Wooldridge, Jeffrey M. (2013) Introductory Econometrics: A Modern Approach, 5th, South-Western, Cengage Learning.

Wright, Carl N. and Booker,Q. (2010) "The Effects of A Cooling-Off Period On Perceived Independence of External Auditors: A Study In The Non-public Regulatory Environment", Research in Accounting Regulation, 22(1), pp. 47-51,ISSN 10520457,https://doi.org/10.1016/j.racreg.2009.11.003

Zang, Amy Y. (2012) "Evidence on the Trade-Off between Real Activities Manipulation and Accrual-Based Earnings Management", The Accounting Review, 87(2), pp. 675-703. DOI:10.2308/accr-10196 